\title{
Assessment of Directed Land Use Development in Chennai Metropolitan Area
}

\author{
Sampath Kumar V', Helen Santhi $\mathbf{M}^{2}$ \\ ${ }^{12}$ Professor, Department of Civil Engineering, Sathyabama University, Chennai, India \\ e-mail: vsampath33kumar@yahoo.co.in, mhelensanthi@yahoo.com
}

\begin{abstract}
Chennai Metropolitan Area spreads over 1189 square kilometers. The trend of its growth is very short and steep. The rapid developments increase the density of population and utilize urban land in a large scale. Land is the basic need for any type of development and it becomes a scarce commodity. So pre-planning of the land use is necessary. Chennai Metropolitan Development Authority categories the urban land into various zones and advocates the planned way of development. Later on based on the request a reclassification scheme is introduced to change the use of urban land. To assess the directed land use development in Chennai Metropolitan Area, a study is conducted along the four major arterials on few selected locations. The physical developments in selected locations are compared with the land use maps. From the study it is concluded that the physical development follow the directed pattern with minor deviation
\end{abstract}

Key words: Madras Metropolitan Development Authority, Chennai Metropolitan Development Authority, Development Control Rule, Detailed Development Plan

\section{I.INTRODUCTION}

Chennai is the Capital City of Tamil Nadu and is the fourth largest Metropolitan City in India. Chennai city spreads over 176 square kilometers. It comprises of 5 Taluks which includes 16 planning divisions. The Greater Chennai (or) Chennai Metropolitan Area (CMA) spreads over 1189 square kilometers. It includes Chennai Municipal Corporation (CMC), 16 Municipalities, 20 Town Panchayats, 10 Panchayat Unions and 214 Village Panchayats. The Chennai Urban agglomeration includes $18 \%$ of Thiruvallur District in the North and $8 \%$ of Kanchipuram District in the South.

Chennai has just 360 years of history and the modern trend of development is very short and steep. Due to the rapid urbanization, multi developments took place in unplanned way which leads to high traffic conjunction with mixed traffic pattern in the City. With its multi activities the City attracts people from many part of the State and the density of population is increased to many fold.

With the increase and concentration of population in urban areas, urban problems have increased. It requires and continues to require restriction in respect of the use and occupation of land in urban areas. In order to regulate the growth of the Metropolitan area in an orderly manner and also to ensure its economic viability, social stability and sound management for the present and the foreseeable future, the Master Plan with zoning and development regulation become necessary.

\section{ZONING OF LAND PARCELS}

To preplan the developments Madras Metropolitan Development Authority (MMDA) was established in 1972 which was renamed as Chennai Metropolitan Development Authority (CMDA). CMDA developed the First Master Plan (FMP) for CMA for 20 years (1971 -1991) during 1975 and it was approved in 1976. The Master Plan advocates the direction of development and it focused on many interactive issues such as demography, defining the city structure, economy, transportation, shelter, infrastructure, social facilities, solid waste management, macro drainage system, disaster management, environment, investment planning, land use planning and on development regulations. The FMP suggested large and medium scale industries to increase tertiary sector employment and to optimize the use of existing infrastructure carefully to face the future demand.

In this regard CMDA started regulating the land use and building development activities by dividing the land into various zones and by imposing Development Control Rule (DCR) respectively. The land parcels were categorized into various zones like primary residential zone, mixed residential zone, commercial zone, institutional zone, light industrial zone, general industrial zone, special and hazardous industrial zone, open space and recreational zone and non urban zone. The zones are clearly earmarked in Detailed Development Plan (DDP) which is said to be a rigid plan. Further developments are forced to follow the zonal regulations.

The idea of zoning is that the segregation of certain uses from others reduces the effect of negative externalities, which some uses have on others. Zoning provides spatial segregation of conflicting uses. It also has the benefit of increasing positive externalities because many uses find an advantage in being grouped with other similar uses. These external effects include air and water 
pollution, excessive noise levels, traffic congestion, and aesthetic disamenities.

Because of its predominant role, modern zoning encompasses expanded objectives for supplying certain public goods such as preservation of open space, prime agriculture land and ecologically sensitive areas also. Zoning is also desired on reduction of costs of providing certain public services.

But on later years the CMDA started reviewing the land use zones periodically, when a large number of requests were received from a particular area on change in the land use. Comprehensive reclassification schemes have been introduced to dilute the rigidity of first master plan, for example reclassification of Poonamallee bypass and Old Mamallapuram Road (OMR).

Now it is expected that the land use development has follows the master plan with minor variations by way of commercial and industrial activities in residential or agricultural areas and the upcoming unapproved layouts in agricultural areas. In the past years reclassification of agricultural zone to primary and mixed residential and institutional zones are significant.

\section{ANALYSIS OF STUDY AREA}

A study is conducted along the four major corridors of Chennai such as Grant North Trunk Road (GNT), Grant West Trunk Road (GWT), Grant South Trunk Road (GST) and OMR. Fig. 1 shows the study area. The study focuses on quantifying the deviation in the directed zonal development stated in DDP. The selected locations are Tondiarpet, Thiruvottriyur and Minjur along GNT road, Ayanavaram, Poonamallee and Sriperumbudur along GWT road, Vivekanadapuram in Mylapore, Kanadasannagar in T.Nagar and Tambaram along GST road and Gandhi nagar in Adyar and Sholinganallur along OMR.

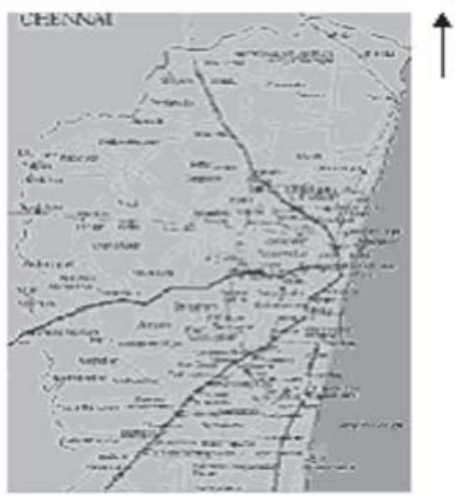

Fig. 1 Study Area
The DDP of the study locations are scanned and digitized using Arch info Geographic Information System (GIS) software. Figs. 2 to 11 show the digitized maps of locations in the study area. The following legends are used to represent the different zones.
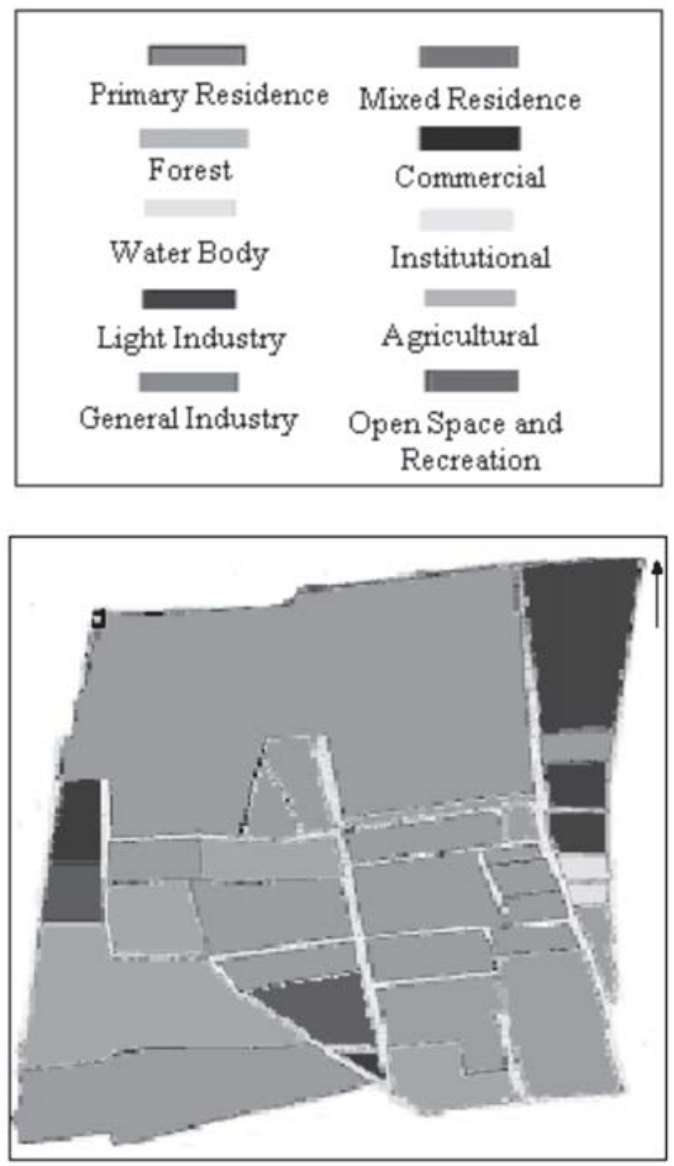

Fig. 2 Zones of Tondiarpet

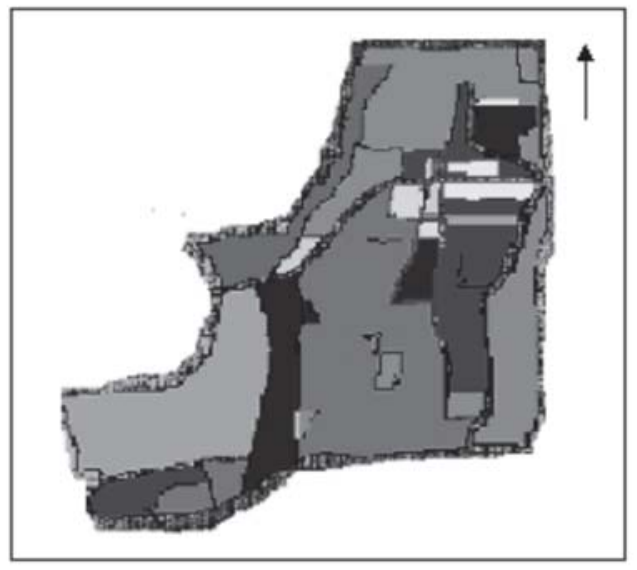

Fig. 3 Zones of Thiruvottriyur 


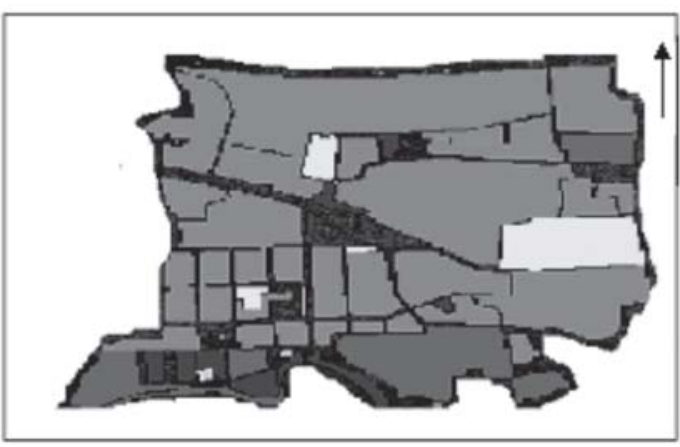

Fig. 4. Zones of Ayanavaram

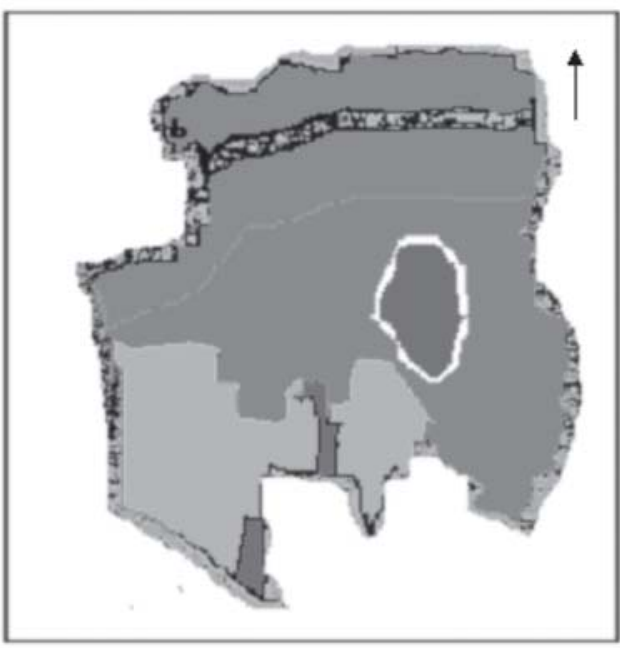

Fig. 5 Zones of Poonamallee

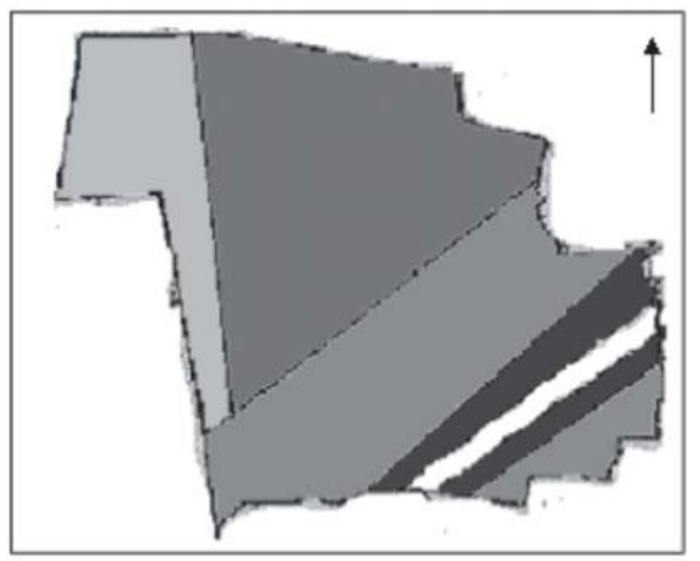

Fig. 6 Zones of Sriperumbudur

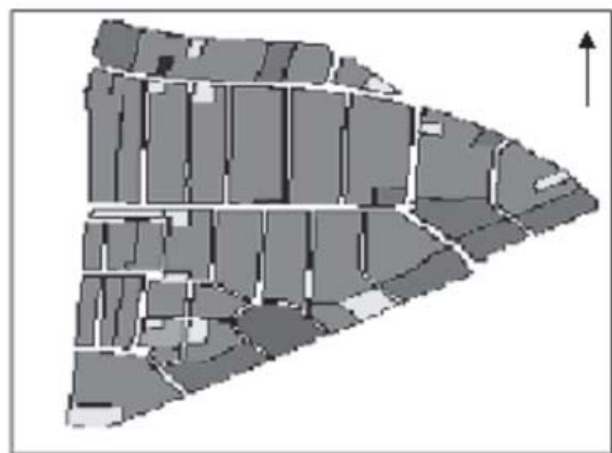

Fig. 7 Zones of Kannadasan Nagar in T.Nagar

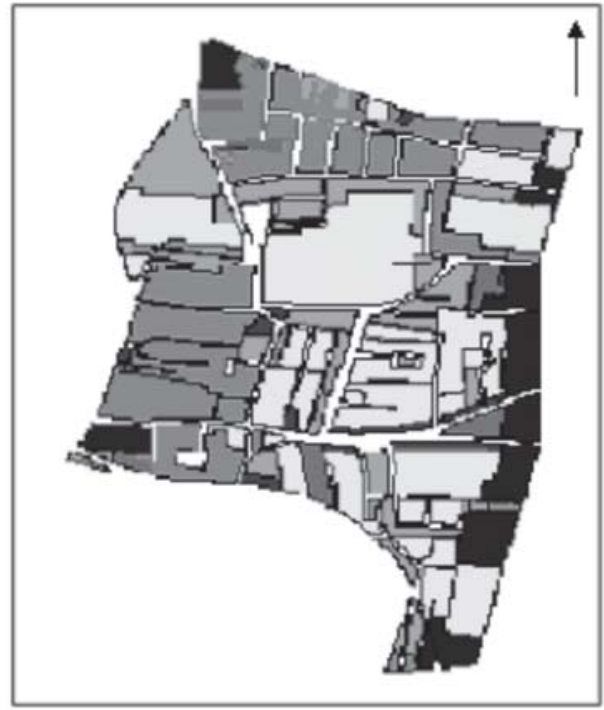

Fig. 8 Zones of Vivekanandapuram in Mylaore

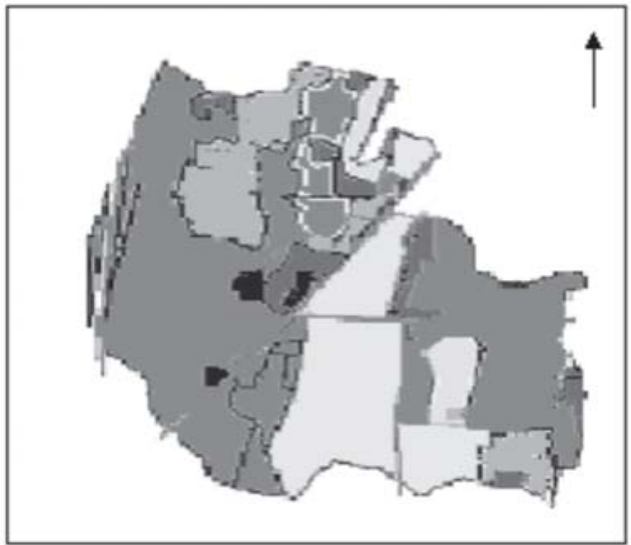

Fig. 9 Zone of Tambaram 


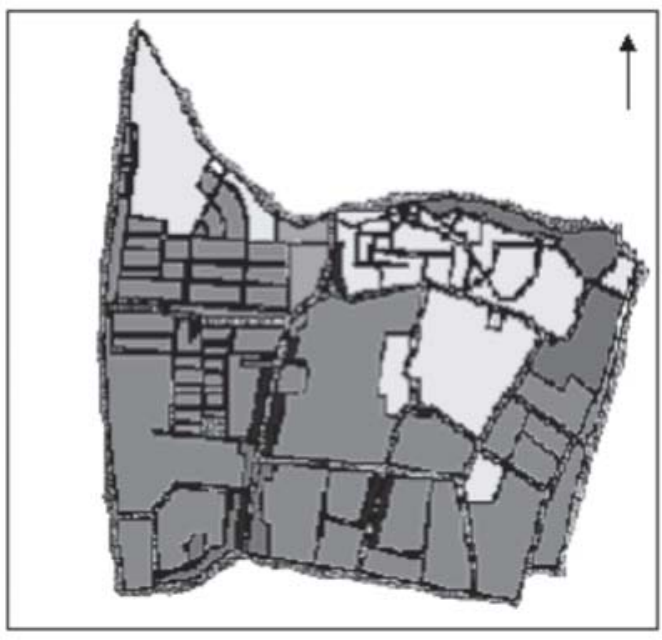

Fig. 10 Zone of Gandhi Nagar in Adyar

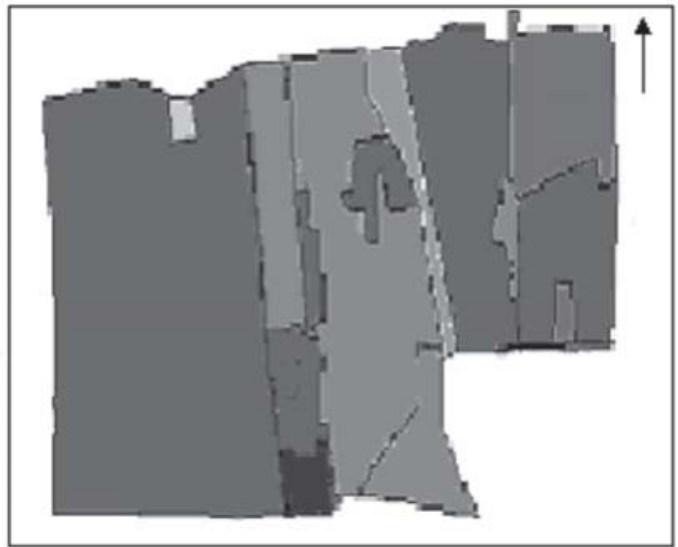

Fig. 11 Zones of Sholinganallur

The informations in each divided zone are collected by queries. After this a field survey on the physical development is made and it is incorporated in the digitized map. The physical development is compared with the directed development and the deviations are tabulated. Tables 1, 2, 3 and 4 show the change in zonal development along the selected corridors. It can be seen that the deviation in mixed residential zone is significant in all the study locations. This may be due to the conversion of primary residential zone into mixed residential zone in these locations.
TABLE 1. CHANGE IN THE ZONE DEVELOPMENT ALONG GNT ROAD

\begin{tabular}{|l|c|c|c|c|}
\hline \multicolumn{1}{|c|}{ Zone } & $\begin{array}{c}\text { Directed } \\
\text { Development } \\
\text { in Sq.m. }\end{array}$ & $\begin{array}{c}\text { Physical } \\
\text { Development } \\
\text { in Sq.m. }\end{array}$ & $\begin{array}{c}\text { Deviation } \\
\text { in Sq.m. }\end{array}$ & $\begin{array}{c}\% \\
\text { Deviation }\end{array}$ \\
\hline $\begin{array}{l}\text { Primary } \\
\text { Residential }\end{array}$ & 344324 & 335899 & 8425 & 2.44 \\
\hline $\begin{array}{l}\text { Mixed } \\
\text { Residential }\end{array}$ & 187639 & 196064 & 7992 & 4.50 \\
\hline Commercial & 28554 & 28554 & 0 & 0.00 \\
\hline Institutional & 1113 & 1113 & 0 & 0.00 \\
\hline $\begin{array}{l}\text { Light and } \\
\text { General } \\
\text { Industry }\end{array}$ & 56343 & 56776 & 433 & 0.80 \\
\hline $\begin{array}{c}\text { Open space } \\
\text { and } \\
\text { Recreational }\end{array}$ & 91232 & 91232 & 0 & 0.00 \\
\hline
\end{tabular}

TABLE 2. CHANGE IN THE ZONE DEVELOPMENT ALONG GWT ROAD

\begin{tabular}{|l|c|c|c|c|}
\hline \multicolumn{1}{|c|}{ Zone } & $\begin{array}{c}\text { Directed } \\
\text { Development } \\
\text { in Sq.m. }\end{array}$ & $\begin{array}{c}\text { Physical } \\
\text { Development } \\
\text { in Sq.m. }\end{array}$ & $\begin{array}{c}\text { Deviation } \\
\text { in Sq.m. }\end{array}$ & $\begin{array}{c}\% \\
\text { Deviation }\end{array}$ \\
\hline $\begin{array}{l}\text { Primary } \\
\text { Residential }\end{array}$ & 36783 & 32929 & 3854 & 10.40 \\
\hline $\begin{array}{l}\text { Mixed } \\
\text { Residential }\end{array}$ & 22889 & 26743 & 3854 & 16.80 \\
\hline Commercial & 15433 & 15433 & 0 & 0.00 \\
\hline $\begin{array}{l}\text { General } \\
\text { Industry }\end{array}$ & 12234 & 12234 & 0 & 0.00 \\
\hline $\begin{array}{c}\text { Open space } \\
\text { and } \\
\text { Recreational }\end{array}$ & 453555 & 453555 & 0 & 0.00 \\
\hline
\end{tabular}

TABLE 3. CHANGE IN THE ZONE DEVELOPMENT ALONG GST ROAD

\begin{tabular}{|l|c|c|c|c|}
\hline \multicolumn{1}{|c|}{ Zone } & $\begin{array}{c}\text { Directed } \\
\text { Development } \\
\text { in Sq.m. }\end{array}$ & $\begin{array}{c}\text { Physical } \\
\text { Development } \\
\text { in Sq.m. }\end{array}$ & $\begin{array}{c}\text { Deviation } \\
\text { in Sq.m. }\end{array}$ & $\begin{array}{c}\% \\
\text { Deviation }\end{array}$ \\
\hline $\begin{array}{l}\text { Primary } \\
\text { Residential }\end{array}$ & 645340 & 643590 & 1750 & 0.30 \\
\hline $\begin{array}{l}\text { Mixed } \\
\text { Residential }\end{array}$ & 166886 & 168616 & 1750 & 1.05 \\
\hline Commercial & 122698 & 122698 & 0 & 0.00 \\
\hline Institutional & 171570 & 171570 & 0 & 0.00 \\
\hline $\begin{array}{l}\text { General } \\
\text { Industry }\end{array}$ & 14750 & 14750 & 0 & 0.00 \\
\hline Agricultural & 2959 & 2959 & 0 & 0.00 \\
\hline Forest & 8769 & 8769 & 0 & 0.00 \\
\hline $\begin{array}{c}\text { Open space } \\
\text { and }\end{array}$ & 3840 & 3840 & 0 & 0.00 \\
Recreational & & & & \\
\hline
\end{tabular}

TABLE 4. CHANGE IN THE ZONE DEVELOPMENT ALONG OMR

\begin{tabular}{|l|c|c|c|c|}
\hline \multicolumn{1}{|c|}{ Zone } & $\begin{array}{c}\text { Directed } \\
\text { Developmen } \\
\text { t in Sq.m. }\end{array}$ & $\begin{array}{c}\text { Physical } \\
\text { Development } \\
\text { in Sq.m. }\end{array}$ & $\begin{array}{c}\text { Deviati } \\
\text { on in } \\
\text { Sq.m. }\end{array}$ & $\begin{array}{c}\% \\
\text { Deviation }\end{array}$ \\
\hline $\begin{array}{l}\text { Primary } \\
\text { Residential }\end{array}$ & 64854 & 63238 & 1616 & 2.50 \\
\hline $\begin{array}{l}\text { Mixed } \\
\text { Residential }\end{array}$ & 22311 & 23872 & 1561 & 7.00 \\
\hline Commercial & 10240 & 10240 & 0 & 0.00 \\
\hline Institutional & 245585 & 245640 & 55 & 0.03 \\
\hline $\begin{array}{l}\text { Light and } \\
\text { General } \\
\text { Industry }\end{array}$ & 1968000 & 1968000 & 0 & 0.00 \\
\hline $\begin{array}{l}\text { Open space } \\
\text { and } \\
\text { Recreational }\end{array}$ & 5624688 & 5624688 & 0 & 0.00 \\
\hline
\end{tabular}




\section{CONCLUSION}

The change in physical developments is studied along the selected corridors and it is found that there is a significant deviation in mixed residential zone. The other land zones remain almost unchanged. From the study it is concluded that the objective of FMP regarding land use zoning is achieved with a minimum deviation.

\section{REFERENCES}

[1] Detailed Development Plan, Proposed Land use maps, CMDA.

[2] Master Plan for Madras Metropolitan Area 2011, Draft, CMDA, July 1995.
[3] Oapos, Hara, C.G., King, J.S., Cartwright, J.H., King, R.L. "Multitemporal Land use and Land cover classification of urbanized areas within sensitive coastal environments". Geoscience and Remote Sensing, IEEE Transactions on Volume 41, Issue 9 , Sep., 2003 Page (s), 2005-2014.

[4] Raghavswamy, V, Rajivkumar and Rakesh Paliwal,"Application of GPS and GIS in satellite Remote Sensing assessment of land-use and landresource pattern in limestone mining area and environs at Wadi, Gulbarga district, Karnataka.

[4] Wishwakarma, R.K, "Land and property values", Center for urban studies, The Institute of Public Administration, New Delhi. 